\title{
HIGH BASAL METABOLIC RATES OF SHOREBIRDS WHILE IN THE ARCTIC: A CIRCUMPOLAR VIEW
}

\author{
ÅKE LindSTRÖM $^{1,3}$ AND MARCEl KLAASSEN ${ }^{2}$ \\ ${ }^{1}$ Department of Ecology, Animal Ecology, Lund University, Ecology Building, S-22362 Lund, Sweden, and \\ Netherlands Institute for Sea Research (NIOZ), PO Box 59, NL-1790 AB Den Burg, Texel, Netherlands \\ ${ }^{2}$ Centre for Limnology, Netherlands Institute of Ecology (NIOO-KNAW), P.O. Box 1299, \\ 3600 BG Maarsen, Netherlands
}

\begin{abstract}
The basal metabolic rate (BMR) of Old World long-distance-migrant shorebirds has been found to vary along their migration route. On average, BMR is highest in the Arctic at the start of fall migration, intermediate at temperate latitudes, and lowest on the tropical wintering grounds. As a test of the generality of this pattern, we measured the BMR of one adult and 44 juvenile shorebirds of 10 species (1-18 individuals of each species, body-mass range 19-94 g) during the first part of their southward migration in the Canadian Arctic $\left(68-76^{\circ} \mathrm{N}\right)$. The interspecific relationship between BMR and body mass was almost identical to that found for juvenile shorebirds in the Eurasian Arctic (5 species), although only one species appeared in both data sets. We conclude that high BMR of shorebirds in the Arctic is a circumpolar phenomenon. The most likely explanation is that the high BMR reflects physiological adaptations to low ambient temperatures. Whether the BMR of New World shorebirds drops during southward migration remains to be investigated.
\end{abstract}

Key words: BMR, Canada, indirect calorimetry, migration, physiological adaptation.

Altas Tasas Metabólicas Basales de Aves Playeras Mientras Se Encuentran en el Ártico: Una Visión Circumpolar

Resumen. Se ha encontrado que la tasa metabólica basal (TMB) de las aves playeras migratorias de larga distancia varía a lo largo de sus rutas de migración en el viejo mundo. En promedio, la TMB es máxima al comienzo de la migración otoñal en el ártico, intermedia en latitudes templadas y mínima en las áreas tropicales de invernada. Para poner a prueba la generalidad de este patrón, medimos la TMB de un individuo adulto y 44 juveniles de diez especies de aves playeras (1-18 individuos de cada especie, rango de peso corporal 19-94 g) durante la primera parte de su migración hacia el sur en el ártico canadiense (68$76^{\circ} \mathrm{N}$ ). La relación interespecífica entre la TMB y el peso corporal fue casi idéntica a la que se había encontrado en juveniles de 5 especies de aves playeras en el ártico de Eurasia, aunque sólo una especie fue considerada en ambos estudios. Concluimos que la alta TMB de las aves playeras en el ártico representa un fenómeno circumpolar. La explicación más probable es que las altas TMBs reflejan adaptaciones fisiológicas a ambientes de bajas temperaturas. Aún no se ha investigado si las TMBs de las aves playeras del nuevo mundo disminuyen durante la migración hacia el sur.

\section{INTRODUCTION}

As a consequence of their long migrations, many Arctic-breeding shorebirds face huge variation in environmental conditions throughout the annual cycle, varying from cold and windy during breeding (or wintering), to hot and dry during migration stopover or wintering along tropical shores. These variations may necessitate metabolic acclimatization, which can be achieved in part by changing the size and metabolic intensity of organs (Piersma and Lindström 1997).

Manuscript received 22 October 2002; accepted 10 March 2003.

${ }^{3}$ E-mail: ake.lindstrom@zooekol.lu.se
The basal metabolic rate (BMR) is not only an important part of an animal's daily energy expenditure (normally $>25 \%$, Drent and Daan 1980), it also may reflect the size and activity level of an animal's organs and tissues. BMR is defined as the energy expenditure of an animal at rest in thermoneutrality during the inactive phase of the day, when it is not processing food and not growing, molting, or reproducing (Aschoff and Pohl 1970). Many studies have reported that BMR correlates positively to the size of metabolically highly active organs (Daan et al. 1990, Konarzewski and Diamond 1994, Piersma et al. 1996). Given that animals can rapidly and repeatedly vary the size of metaboli- 
cally active organs and tissues (Piersma and Lindström 1997), the BMR of an animal may give information about physiological processes and adaptations to the environment.

BMR has been reported to vary between taxonomic groups (Lasiewski and Dawson 1967, Aschoff and Pohl 1970). Shorebirds have been suggested to have higher BMR than other nonpasserines (Kersten and Piersma 1987), although more robust statistical analyses cast doubt on this (Reynolds and Lee 1996, Rezende et al. 2002). A complicating fact for such analyses is that the BMR of a given bird or species is not static (Kvist and Lindström 2001). Studies of migrating birds have shown that BMR can change by up to $40 \%$ within only a few days, parallel to rapid changes in body mass and organ sizes (Klaassen and Biebach 1994, Lindström et al. 1999, Kvist and Lindström 2001, Battley et al. 2000, 2001).

BMR may also vary over season. Kvist and Lindström (2001) compared BMR in juveniles of Arctic shorebirds in the midst of their fall migration (southern Sweden), to BMR in juveniles at the start of their fall migration in the Eurasian Arctic (Lindström 1997), and to BMR of shorebirds at their tropical wintering grounds in Africa (Kersten et al. 1998). On average, BMR was highest in the Arctic, intermediate at temperate latitudes during migration, and lowest at the wintering grounds, with a ratio of 100:84: 77 , respectively.

Why is BMR highest while birds are in the Arctic? Four different explanations have been proposed. (1) High BMR may reflect a physiological adaptation to high energetic demands during migration (Kersten and Piersma 1987, Lindström 1997). Kvist and Lindström (2001) rejected this hypothesis since they found that BMR had dropped while there was still much migration to be carried out. Alternatively, (2) BMR in the Arctic may be relatively high in juveniles because there is still some latent effect of growth (cf. Ricklefs 1974, Hume and Biebach 1996, Guglielmo 1999, Kvist and Lindström 2001). It has also been suggested that (3) BMR is low in the tropics to avoid heat stress by minimizing endogenous heat production (Weathers 1980, Klaassen et al. 1990, Klaassen and Drent 1991, Klaassen 1995). Following this line of argument, BMR should be highest in the Arctic, where thermoregulatory costs are likely to be highest (Wiersma and Piersma 1994). Kvist and
Lindström (2001) suggested that (4) the variation in BMR between sites might simply reflect physiological adaptations to local ecological conditions and demands at each site independent of temperature and geographic region. For example, differences in food types, supply, or demand at different sites could cause differences in the size of food processing organs (Guglielmo 1999), which could influence BMR.

It is not clear whether the BMR change over time in shorebirds migrating from the Eurasian Arctic to Africa (Lindström 1997, Kersten et al. 1998, Kvist and Lindström 2001) is representative for shorebirds in other parts of the world, and for migrants in general. For shorebirds, too little data are available to allow such comparisons. The aim of our study was to test the generality of the pattern found for shorebirds in the Old World, by measuring a separate set of shorebird species under similar conditions in the New World High Arctic. We also set out to test whether BMR changes over time within the Arctic. If the high BMR values of the Arctic are influenced by some latent effect of growth, we would expect BMR to drop as summer progresses.

\section{METHODS}

In summer 1999, we participated in the shipborne Swedish-Canadian expedition "Tundra Northwest 1999" (Grönlund 2000). From 4-31 August 1999 we visited 8 different sites in Arctic Canada, from Ivvavik National Park, Yukon, in the west, to Baffin Island, Nunavut, in the east. At each site we spent $24-48 \mathrm{hr}$ trying to trap shorebirds, succeeding at six sites (Fig. 1). Shorebirds were trapped in walk-in traps and mist nets, mainly along brooks, shorelines, and ponds (Lindström et al. 2002). Between 3 and 12 birds from each site were flown by helicopter to the expedition ship for metabolic measurements. On the ship the birds were kept in boxes $(0.5 \mathrm{~m} \times 0.7 \mathrm{~m} \times 0.5 \mathrm{~m})$ in an undisturbed room with daylight from a small window and additional electrical light (simulating outdoor conditions). There was continuous daylight at sites 10-12 (Fig. 1). At sites 15-17 there were approximately 1,3 , and $6 \mathrm{hr}$ of darkness, respectively. The birds were provided with freshwater for drinking and bathing twice a day.

Subcutaneous fat stores in the tracheal pit were scored using a scale from 0 to 6 following Pettersson and Hasselquist (1985). Fat score 0 reflects no visible fat. In fat score 6 the tracheal 


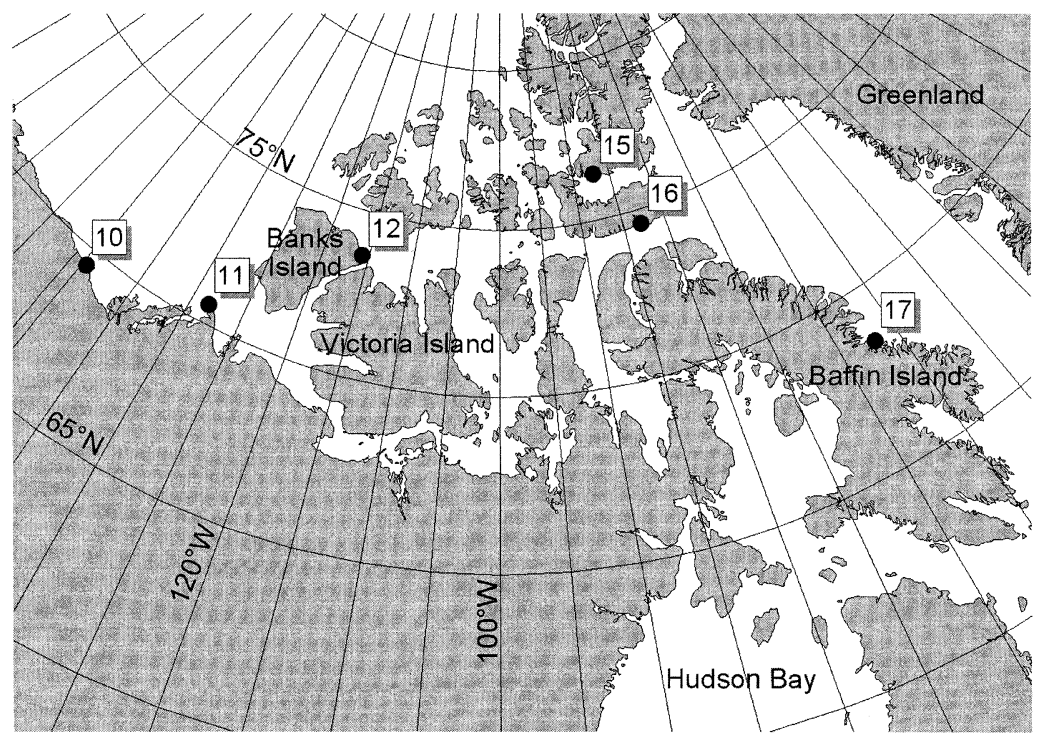

FIGURE 1. The location of the six sites (with their original expedition number) in the Canadian Arctic where shorebirds were caught for metabolic measurements in 1999. Locations and dates of visit of each site: site 10: Ivvavik National Park, Firth River delta $\left(69^{\circ} 32^{\prime} \mathrm{N}, 1^{\circ} 39^{\circ} 33^{\prime} \mathrm{W}\right), 4-5$ August; site 11: Cape Bathurst, Baillie Island

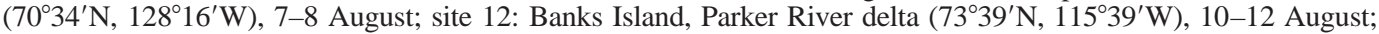
site 15: Ellesmere Island, Muskox Fiord $\left(7^{\circ} 25^{\prime} \mathrm{N}, 87^{\circ} 06^{\prime} \mathrm{W}\right), 20-23$ August; site 16: Devon Island, Dundas Harbor $\left(74^{\circ} 33^{\prime} \mathrm{N}, 82^{\circ} 50^{\prime} \mathrm{W}\right), 25-26$ August; site 17: Baffin Island, Cape Hooper $\left(68^{\circ} 25^{\prime} \mathrm{N}, 66^{\circ} 56^{\prime} \mathrm{W}\right), 30-31$ August.

pit is filled and bulging fat extends to the side of the throat. This scale was created for studies of passerines, but has proven to work well for smaller shorebirds too (Lindström 1998). The shorebirds measured in earlier studies (Lindström 1997, Kersten et al. 1998, Kvist and Lindström 2001) were fairly lean. To allow comparison we therefore aimed at measuring birds with low fat scores. Most birds were already low in fat when we trapped them (Lindström et al. 2002), so we gave small amounts of mealworms (Tenebrio sp.) to birds that we kept longer on the ship, to keep their body mass and visual fat stores stable and low. A few Buff-breasted Sandpipers (Tryngites subruficollis) were comparatively fat when trapped (fat score 4-6), and these birds were given no or only tiny amounts of supplementary food, to reduce their fat stores to levels comparable to the other species.

Most birds measured were juveniles (birds hatched the same year). Only birds that had fully grown primaries (no feather sheaths) were measured, to avoid measuring juvenile birds still growing (Lindström 1997). Although we avoided measuring birds with growing feathers, a handful of the birds had some tiny traces of down in neck. The birds were kept on average
$48 \mathrm{hr}$ (range 6-109 hr) between capture and metabolic measurements. Before and after the overnight metabolic measurements the birds were weighed with a Pesola spring balance to the nearest 0.1 or 1 gram (depending on size). The birds were released ashore, or from the ship's helicopter deck, within two days following the measurements.

\section{METABOLIC MEASUREMENTS}

Metabolic rates were estimated from measurements of oxygen consumption in an open-circuit system. Measurements started between 18:00 and 20:00 local time and ended between 06:00 and 07:00 the following day. The volume of the metabolic chambers (made of Perspex) was varied using plastic blocks, so that the volume was $5 \mathrm{~L}$ for the smallest birds and $7 \mathrm{~L}$ for the largest birds. No food or water was given during the measurements. The metabolic chambers were placed in complete darkness in a temperature cabinet set to give the birds an ambient temperature of $25.5^{\circ} \mathrm{C}\left( \pm 0.5^{\circ} \mathrm{C}\right)$. The lower critical temperature of small shorebird species is poorly known (Kersten et al. 1998), but is likely to be around $25-26^{\circ} \mathrm{C}$ (Kvist and Lindström 2001). Therefore, most if not all of our birds were mea- 
sured under thermoneutral conditions, with the possible exception of the very smallest $(20 \mathrm{~g})$ birds. However, for a comparison with the data by Lindström (1997) and Kvist and Lindström (2001) this is of less importance, since the temperature and general setup were close to identical in the three studies.

Air was led through the system in the following order: metabolic chamber, dryer (silica gel), pump, flow controller (F-210C-FA-22-V, Bronkhorst High Tech, Ruurlo, Netherlands), oxygen analyzer (Xentra 41002A1, Servomex, Crowborough, East Sussex, UK) and carbon dioxide analyzer (Servomex 1440C, Servomex). The analyzers were zero-calibrated using $\mathrm{N}_{2}$ gas with $99.998 \%$ purity, and the carbon dioxide analyzer was span-calibrated with a mixture of $\mathrm{CO}_{2}$ $(0.892 \%)$ and $\mathrm{N}_{2}$ (the rest). Whereas up to four birds were measured each night, the setup allowed measurement of only two birds simultaneously (two birds connected to each of two measuring cells). The two birds in each cell were measured consecutively, alternating every 25 min. Reference air was sampled during $15 \mathrm{~min}$ every $90 \mathrm{~min}$. In this way, each bird was measured for about $40 \%$ of the night. The airflow used depended on the size of the bird and was controlled at 15.0 or $20.0 \mathrm{~L} \mathrm{hr}^{-1}$ (dry air at $0^{\circ} \mathrm{C}$ and $1013 \mathrm{hPa}$, with a maximum error of the flow of $\pm 1.4 \%$, according to the manufacturer).

Data on oxygen concentration and temperature were stored every minute on a data-logger (Grant SQ 1202, Grant Instruments, Shepreth, UK). Oxygen consumption and carbon dioxide production was corrected for the difference in volume of inlet and outlet air (Klaassen et al. 1997). The average respiratory quotient (RQ) was 0.71. For the estimate of BMR we used the lowest 10-min average of oxygen consumption, using an energetic equivalent of $19.8 \mathrm{~kJ} \mathrm{~L}^{-1}$ oxygen consumed. The median time of day for the lowest 10-min averages was 04:11 local time (range 22:43-06:58). The relatively small variations in oxygen consumption recorded over night indicated that the birds were asleep, or at least inactive, during most of the night. Given that measurements lasted for about $12 \mathrm{hr}$, and most birds had been without food the preceding 4-6 hr, or had been fed only 1-2 g of mealworms, we feel confident that any effect of food processing on oxygen consumption was of no or only minor importance for the BMR estimates (Klaassen and Biebach 1994). The body mass reported is the evening mass before measurements started, following Lindström (1997) and Kvist and Lindström (2001).

\section{STATISTICAL ANALYSES}

Statistics were conducted using Statistica (StatSoft, Inc. 1999). All statistics were conducted on $\log _{10}$-transformed values for body mass and BMR; that is, species averages are presented as geometric means. Following Pagel and Harvey (1988) and Kvist and Lindström (2001) we used reduced major axis (RMA) regression to describe interspecific allometric relationships.

\section{RESULTS}

We measured 45 birds, of which 44 were juveniles (Table 1). The only adult bird was a female Pectoral Sandpiper (Calidris melanotos) trapped at site 10 . In a study of migratory shorebirds in southern Sweden, Kvist and Lindström (2001) found no consistent pattern of differences in BMR due to age. We therefore included this female in the analysis. Among the 195 juveniles trapped in Canada, $42 \%$ had traces of down on their heads. The proportion varied greatly between species and sites, but fell from $46 \%$ at sites $10-12$ to $28 \%$ at sites 15-17 $\left(\chi^{2}{ }_{1}=4.9, P=0.03\right)$.

Species averages for BMR varied from $0.31 \mathrm{~W}$ in the Semipalmated Sandpiper (Calidris pusilla) to $0.99 \mathrm{~W}$ in the Ruddy Turnstone (Arenaria interpres; Appendix). The interspecific RMA relationship between BMR and body mass $(M$, in g) was BMR $=0.037 M^{0.71}\left(F_{1,8}=107.0, r^{2}=0.93\right.$, $P<0.001, n=10$ species, Fig. 2). This is very similar to the relationship presented by Lindström (1997) for juveniles of five species of shorebirds from the Eurasian Arctic $\left(\mathrm{BMR}=0.041 M^{0.69}\right.$; RMA, recalculated by Kvist and Lindström 2001). More formally, there was no significant effect of region (Canada vs. Eurasia) on BMR (ANCOVA: locality: $F_{1,12}=0.0001, P=0.99$; mass: $\left.F_{1,12}=186.8, P<0.001\right)$. Only one species (Ruddy Turnstone) occurred in both datasets. After combining the values for the Ruddy Turnstones from Canada and Eurasia, the combined circumpolar interspecific relationship (RMA) for the 14 species measured was $\mathrm{BMR}=0.040 M^{0.69}$ $\left(F_{1,12}=152.8, r^{2}=0.93, P<0.001\right.$, Table 1$)$.

Including data from both Eurasia (Lindström 1997) and Canada (this study), we tested for an effect of date (5 August-1 September) on BMR in an ANCOVA, including body mass and date as covariates and region and species as catego- 

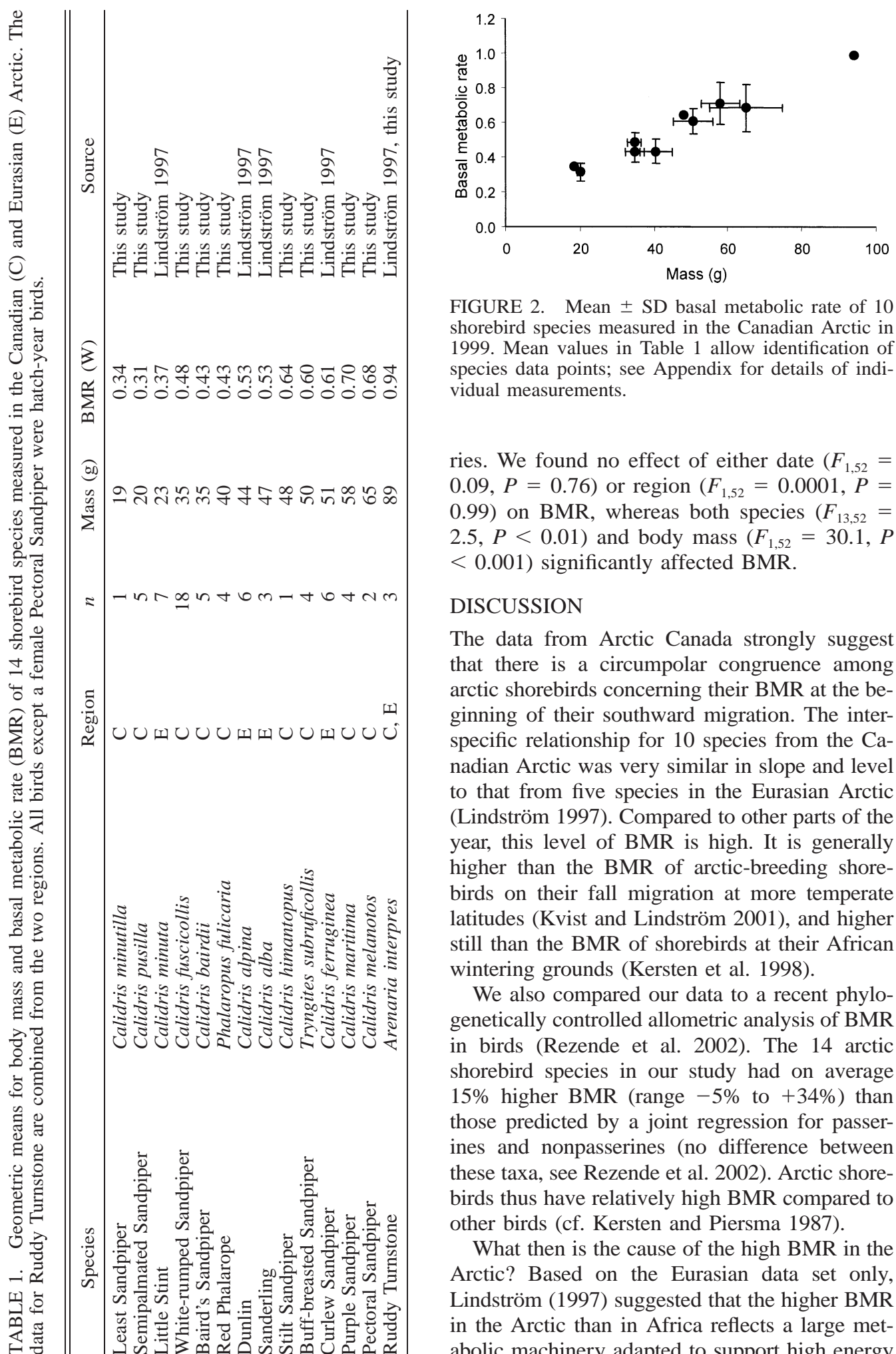

FIGURE 2. Mean \pm SD basal metabolic rate of 10 shorebird species measured in the Canadian Arctic in 1999. Mean values in Table 1 allow identification of species data points; see Appendix for details of individual measurements.

ries. We found no effect of either date $\left(F_{1,52}=\right.$ $0.09, P=0.76)$ or region $\left(F_{1,52}=0.0001, P=\right.$ 0.99) on BMR, whereas both species $\left(F_{13,52}=\right.$ $2.5, P<0.01)$ and body mass $\left(F_{1,52}=30.1, P\right.$ $<0.001)$ significantly affected BMR.

\section{DISCUSSION}

The data from Arctic Canada strongly suggest that there is a circumpolar congruence among arctic shorebirds concerning their BMR at the beginning of their southward migration. The interspecific relationship for 10 species from the Canadian Arctic was very similar in slope and level to that from five species in the Eurasian Arctic (Lindström 1997). Compared to other parts of the year, this level of BMR is high. It is generally higher than the BMR of arctic-breeding shorebirds on their fall migration at more temperate latitudes (Kvist and Lindström 2001), and higher still than the BMR of shorebirds at their African wintering grounds (Kersten et al. 1998).

We also compared our data to a recent phylogenetically controlled allometric analysis of BMR in birds (Rezende et al. 2002). The 14 arctic shorebird species in our study had on average $15 \%$ higher BMR (range $-5 \%$ to $+34 \%$ ) than those predicted by a joint regression for passerines and nonpasserines (no difference between these taxa, see Rezende et al. 2002). Arctic shorebirds thus have relatively high BMR compared to other birds (cf. Kersten and Piersma 1987).

What then is the cause of the high BMR in the Arctic? Based on the Eurasian data set only, Lindström (1997) suggested that the higher BMR in the Arctic than in Africa reflects a large metabolic machinery adapted to support high energy 
turnover rates during migration (cf. Kersten and Piersma 1987). Kvist and Lindström (2001) rejected this hypothesis because BMR was considerably lower in the same and related species at a stopover site about midway through fall migration. Kvist and Lindström (2001) therefore suggested that the relatively high BMR in the Arctic could be due to some latent effect of growth (cf. Ricklefs 1974, Hume and Biebach 1996, Guglielmo 1999). Our analysis showed that BMR did not change with date. Although we cannot be certain that the birds measured late in season were older than the birds measured early in season, it still is a reasonable assumption. Support for the assumption comes from the decreasing proportion of downy juveniles with date. We therefore tentatively reject the hypothesis that high BMR is due to a latent effect of growth.

The two remaining explanations to high BMR in the Arctic, that is, adaptations to high thermoregulatory costs, and physiological adaptations to local ecological conditions independent of temperature differences, remain to be tested. The first of these is a likely candidate since thermoregulatory costs in the High Arctic are likely to be high (Wiersma and Piersma 1994). Experimental evidence exists that both birds and mammals adjust the size of energy-consuming organs such as liver, kidney, and the digestive tract to cold temperatures (Williams and Tieleman 2000, Hammond et al. 2001), something that leads to an increase in BMR (Daan et al. 1990, Weber and Piersma 1996, Williams and Tieleman 2000).

Does BMR of New World arctic shorebirds drop over the season, as in Old World shorebirds? We found only three studies presenting BMR data from New World shorebirds, namely Sanderling (Calidris alba; Castro 1987), Pacific Golden-Plover (Pluvialis fulva; Mathiu et al. 1989), and American Woodcock (Scolopax minor; Vander Haegen et al. 1994). The last is not an arctic species, and the first two species, although arctic breeders, were not included in our study. Therefore, no direct comparisons are possible. The Sanderlings and Pacific Golden-Plovers were measured on their tropical wintering grounds in Peru (Castro 1987) and on Hawai'i (Mathiu et al. 1989), respectively. Assuming that these species would have a BMR according to our general arctic relationship $\left(\mathrm{BMR}=0.040 M^{0.69}\right)$ while in the Arctic, we would expect their BMR to be $0.60 \mathrm{~W}$ and $1.13 \mathrm{~W}$, respectively. The recorded values were
$0.58 \mathrm{~W}$ and $1.31 \mathrm{~W}$, which are $0.3 \%$ lower and $16 \%$ higher than predicted by the arctic equation. This speaks against relatively low BMR in the tropics. However, the Sanderlings and plovers were measured during daytime, which may have overestimated BMR by up to $30 \%$ (Aschoff and Pohl 1970).

Clearly, more data on BMR of Arctic shorebirds along their New World migration route are needed. Further, there are only three shorebird species for which data are available on BMR for different age classes, and this from only one site (Kvist and Lindström 2001). Data on how BMR differs between age classes, and how BMR varies seasonally within age classes, will help understanding the reasons for seasonal variation in shorebird BMR.

\section{ACKNOWLEDGMENTS}

We are very grateful to the Swedish Polar Research Secretariat allowing us to participate in their well-organized "Tundra Northwest 1999" expedition and to CCGS Louis S. St-Laurent and its crew for providing such excellent logistics. S. Lidström, J.-E. Johansson, S. Åkesson, U. Ottosson, L. Amagoalik, M. Joe, M. Green, and G. A. Gudmundsson helped with catching birds and made pleasant company in the field. M. Green and G. A. Gudmundsson also helped with respirometer measurements. Trapping permits were obtained thanks to generous help from L. Metras, R. I. G. Morrison, and C. Gratto-Trevor. Thanks also to the Nunavut authorities, Canadian Wildlife Service (Permits 10363 HB and Nun-Sci-99-14), and Yukon National Parks for permits to carry out research at the different sites. The research was approved by the animal care committee of CWS (\#99M99GM5). Our study was supported by a PIONIER grant of the Netherlands Organization for Scientific Research (NWO) to Theunis Piersma, and by grants from the Swedish Natural Science Research Council (NFR) to Å. This is publication no. 3151 of Centre for Limnology, The Netherlands Institute of Ecology (NIOO-KNAW), and publication 331 of the Centre for Wetland Ecology.

\section{LITERATURE CITED}

Aschoff, J., AND H. Pohl. 1970. Der Ruheumsatz von Vögeln als Funktion der Tageszeit und der Körpergrösse. Journal für Ornithologie 111:38-47.

Battley, P. F., A. Dekinga, M. W. Dietz, T. Piersma, S. TANG, AND K. Hulsman. 2001. Basal metabolic rate declines during long-distance migratory flight in Great Knots. Condor 103:838-844.

Battley, P. F., T. Piersma, M. W. Dietz, S. Tang, A. Dekinga, and K. Hulsman. 2000. Empirical evidence for differential organ reductions during trans-oceanic bird flight. Proceedings of the Royal Society of London Series B 267:191-195.

Castro, G. 1987. High basal metabolic rate in Sanderlings (Calidris alba). Wilson Bulletin 99:267-268. 
DaAn, S., D. Masman, And A. Groenewold. 1990. Avian basal metabolic rates: their association with body composition and energy expenditure in nature. American Journal of Physiology 259:R333-340.

DRENT, R. H., AND S. DAAN. 1980. The prudent parent: energetic adjustments in avian breeding. Ardea 68:225-252.

GRÖNLUND, E. [ED.]. 2000. Polarforskningssekretariatets årsbok 1999. Swedish Polar Research Secretariate, Stockholm.

Guglielmo, C. G. 1999. Physiological and biochemical modulation for long-distance migration: the functional significance of intra-specific variation in the Western Sandpiper. Ph.D. dissertation, Simon Fraser University, Vancouver, BC, Canada.

Hammond, K. A., J. SzewCZAK, And E. Król. 2001. Effects of altitude and temperature on organic phenotypic plasticity along an altitudinal gradient. Journal of Experimental Biology 204:1991-2000.

Hume, I. D., And H. Biebach. 1996. Digestive tract function in the long-distance migratory Garden Warbler, Sylvia borin. Journal of Comparative Physiology B 166:388-395.

Kersten, M., and T. Piersma. 1987. High levels of energy expenditure in shorebirds: metabolic adaptations to an energetically expensive way of life. Ardea 75:175-188.

Kersten, M., L. W. Bruinzeel, P. Wiersma, and T. PIERSMA. 1998. Reduced basal metabolic rate of migratory waders wintering in coastal Africa. Ardea 86:76-80.

KLAASSEN, M. 1995. Moult and basal metabolic costs in males of two subspecies of Stonechats: the European Saxicola torquata rubicula and the East African S. t. axillaris. Oecologia 104:424-432.

KlaAssen, M., And H. Biebach. 1994. Energetics of fattening and starvation in the long-distance migratory Garden Warbler, Sylvia borin, during the migratory phase. Journal of Comparative Physiology B 164:362-371.

KlaAssen, M., and R. Drent. 1991. An analysis of hatchling resting metabolism: in search of ecological correlates that explain deviations from allometric relations. Condor 93:612-629.

Klaassen, M., M. Kersten, And B. J. Ens. 1990. Energetic requirements for maintenance and premigratory body mass gain of waders wintering in Africa. Ardea 78:209-220.

KlaAssen, M., Å. Lindström, and R. ZiJlstra. 1997. Composition of fuel stores and digestive limitations to fuel deposition rate in the long-distance migratory Thrush Nightingale Luscinia luscinia. Physiological Zoology 70:125-133.

Konarzewski, M., And J. Diamond. 1994. Peak sustained metabolic rate and its individual variation in cold-stressed mice. Physiological Zoology 67: 1186-1212.

Kvist, A., AND A. LindströM. 2001. Basal metabolic rate in migratory waders: intraindividual, intraspecific, interspecific and seasonal variation. Functional Ecology 15:465-473.

LAsiewski, R. C., AND W. R. Dawson. 1967. A reexamination of the relationship between standard metabolic rate and body weight in birds. Condor 69:13-23.

LINDSTRÖM, А. 1997. Basal metabolic rates of migrating waders in the Eurasian Arctic. Journal of Avian Biology 28:87-92.

LINDSTRÖM, A. 1998. Mass and morphometrics of Little Stints Calidris minuta on autumn migration along the Arctic coast of Eurasia. Ibis 140:171174.

Lindström, Å., M. KlaAssen, And A. Kvist. 1999. Variation in energy intake and basal metabolic rate of a bird migrating in a wind-tunnel. Functional Ecology 13:352-359.

Lindström, Å., M. KlaAssen, T. Piersma, N. HolmGREN, AND L. WENNERBERG. 2002. Fuel stores of juvenile waders on autumn migration in high arctic Canada. Ardea 90:93-101.

Mathiu, P. M., O. W. Johnson, P. M. Johnson, And G. C. Whittow. 1989. Basal metabolic rate of Pacific Golden-Plovers. Wilson Bulletin 101:652-654.

Pagel, M. D., And P. H. Harvey. 1988. The taxonlevel problem in the evolution of mammalian brain size: facts and artefacts. American Naturalist 132:344-359.

Pettersson, J., And D. Hasselquist. 1985. Fat deposition and migration capacity of Robins Erithacus rubecula and Goldcrests Regulus regulus at Ottenby, Sweden. Ringing and Migration 6: 66-76.

Piersma, T., L. Bruinzeel, R. Drent, M. Kersten, J. VAN DER MEER, AND P. WIERSMA. 1996. Variability in basal metabolic rate of a long-distance migrant shorebird (Red Knot, Calidris canutus), reflects shifts in organ sizes. Physiological Zoology 69: 191-217.

PIERSMA, T., AND Å. LindSTRÖM. 1997. Rapid reversible changes in organ size as a component of adaptive behaviour. Trends in Ecology \& Evolution 12: 134-138.

ReYnolds, P. S., AND R. M. LeE III. 1996. Phylogenetic analysis of avian energetics: passerines and nonpasserines do not differ. American Naturalist 147: 735-759.

Rezende, E. L., D. L. Swanson, F. F. Novoa, and F. BozINOVIC. 2002. Passerines versus nonpasserines: so far, no statistical differences in the scaling of avian energetics. Journal of Experimental Biology 205:101-107.

RICKLEFS, R. E. 1974. Energetics of reproduction in birds, p. 152-297. In R. A. Paynter [ED.], Avian energetics. Nuttall Ornithological Club, Cambridge, MA.

StatSoft, Inc. 1999. Statistica version 5.5. StatSoft, Inc., Tulsa, OK.

Vander Haegen, W. M., R. B. Owen, and W. B. KROHN. 1994. Metabolic rate of American Woodcock. Wilson Bulletin 106:338-343.

Weathers, W. W. 1980. Seasonal and geographic variation in avian standard metabolic rate. Proceedings of the International Ornithological Congress 17:283-286. 
Weber, T. P., And T. Piersma. 1996. Basal metabolic rate and the mass of tissues differing in metabolic scope: migration-related covariation between individual Knots, Calidris canutus. Journal of Avian Biology 27:215-224.

Wiersma, P., And T. Piersma. 1994. Effects of microhabitat, flocking, climate and migratory goal on energy-expenditure in the annual cycle of Red Knots. Condor 96:257-279.

Williams, J. B., And B. I. Tieleman. 2000. Flexibility in basal metabolic rate and evaporative water loss among Hoopoe Larks exposed to different environmental temperatures. Journal of Experimental Biology 203:3153-3159.

APPENDIX. Basal metabolic rates of 45 shorebirds measured in the Canadian Arctic in 1999. All birds except a female Pectoral Sandpiper were hatch-year birds. Figure 1 provides locations and names of sites.

\begin{tabular}{|c|c|c|c|c|c|}
\hline Species & Site & $\underset{\text { date }}{\text { Measurement }}$ & $\begin{array}{l}\text { Mass } \\
(\mathrm{g})\end{array}$ & $\begin{array}{l}\text { Fat } \\
\text { score }\end{array}$ & $\frac{\mathrm{BMR}}{(\mathrm{W})}$ \\
\hline Least Sandpiper & 11 & 9 August & 18.5 & 2 & 0.34 \\
\hline \multirow[t]{5}{*}{ Semipalmated Sandpiper } & 10 & 5 August & 20.0 & 1 & 0.30 \\
\hline & 10 & 5 August & 19.5 & 1 & 0.24 \\
\hline & 10 & 5 August & 20.4 & 1 & 0.38 \\
\hline & 10 & 5 August & 20.9 & 2 & 0.33 \\
\hline & 10 & 6 August & 19.0 & 1 & 0.32 \\
\hline \multirow{18}{*}{ White-rumped Sandpiper } & 11 & 9 August & 35.8 & 2 & 0.46 \\
\hline & 11 & 9 August & 33.5 & 1 & 0.44 \\
\hline & 11 & 10 August & 34.2 & 2 & 0.51 \\
\hline & 11 & 10 August & 34.0 & 2 & 0.47 \\
\hline & 15 & 23 August & 33.2 & 1 & 0.47 \\
\hline & 16 & 25 August & 38.1 & 2 & 0.58 \\
\hline & 16 & 25 August & 33.2 & 0 & 0.59 \\
\hline & 16 & 26 August & 33.3 & 1 & 0.52 \\
\hline & 16 & 26 August & 33.1 & 1 & 0.43 \\
\hline & 16 & 26 August & 34.9 & 2 & 0.52 \\
\hline & 16 & 26 August & 33.7 & 1 & 0.49 \\
\hline & 16 & 27 August & 35.6 & 2 & 0.48 \\
\hline & 16 & 27 August & 38.1 & 3 & 0.52 \\
\hline & 16 & 27 August & 33.5 & 2 & 0.48 \\
\hline & 16 & 27 August & 37.6 & 2 & 0.51 \\
\hline & 17 & 31 August & 31.3 & 1 & 0.42 \\
\hline & 17 & 31 August & 35.9 & 2 & 0.46 \\
\hline & 17 & 31 August & 34.8 & 1 & 0.38 \\
\hline \multirow[t]{5}{*}{ Baird's Sandpiper } & 11 & 9 August & 32.3 & 1 & 0.33 \\
\hline & 11 & 10 August & 34.0 & 2 & 0.49 \\
\hline & 11 & 11 August & 39.0 & 3 & 0.47 \\
\hline & 16 & 25 August & 33.6 & 1 & 0.43 \\
\hline & 16 & 25 August & 34.8 & 1 & 0.43 \\
\hline \multirow{4}{*}{ Red Phalarope } & 12 & 11 August & 44.5 & 4 & 0.47 \\
\hline & 12 & 12 August & 35.2 & 0 & 0.33 \\
\hline & 12 & 12 August & 38.7 & 1 & 0.44 \\
\hline & 12 & 13 August & 43.7 & 3 & 0.48 \\
\hline Stilt Sandpiper & 10 & 6 August & 48.0 & 2 & 0.64 \\
\hline \multirow[t]{4}{*}{ Buff-breasted Sandpiper } & 12 & 12 August & 56.0 & 3 & 0.70 \\
\hline & 12 & 12 August & 45.2 & 2 & 0.53 \\
\hline & 12 & 13 August & 54.0 & 2 & 0.62 \\
\hline & 12 & 13 August & 46.8 & 3 & 0.57 \\
\hline \multirow[t]{4}{*}{ Purple Sandpiper } & 15 & 23 August & 53.0 & 1 & 0.60 \\
\hline & 15 & 23 August & 63.0 & 1 & 0.84 \\
\hline & 15 & 24 August & 62.0 & 2 & 0.78 \\
\hline & 15 & 24 August & 54.0 & 1 & 0.62 \\
\hline \multirow[t]{2}{*}{ Pectoral Sandpiper } & 10 & 6 August & $58.0^{\mathrm{a}}$ & $2^{\mathrm{a}}$ & $0.59^{\mathrm{a}}$ \\
\hline & 10 & 6 August & 72.0 & 1 & 0.78 \\
\hline Ruddy Turnstone & 15 & 24 August & 94.0 & 2 & 0.99 \\
\hline
\end{tabular}

a This bird (a female) was the only adult measured. 